\title{
Perancangan Sistem Informasi Perpustakaan Berbasis Web Pada MAN 10 Jakarta Untuk Meningkatkan Minat Belajar Siswa
}

\author{
Eli Fitriatun ${ }^{1}$, Firdha Aprilyani ${ }^{2}$
}

\begin{abstract}
The Library Information System of MAN 10 Jakarta still uses the method recorded, where is borrowing, returning books to reports. so it certainly takes a lot of time to get the desired information or data, therefore we need a library information system that can change time to be more effective, to process loans and repayments automatically and produce information that is certainly fast and precise. In developing the information system that will be designed at MAN 10 Jakarta using the waterfall method, this application uses Codeigniter, PHPMyAdmin as a database and Sublime text 3 for making the information system application. This application or system can simplify the recording process by automating lending and repayment and simplifying the process of making monthly reports and others.

Intisari - Sistem Informasi Perpustakaan MAN 10 Jakarta masih menggunakan cara tercatat, dimana peminjaman, pengembalian buku hingga laporan. sehingga pastinya memakan banyak waktu yang lama untuk mendapatkan informasi atau data yang diingi nkan , karenanya diperlukan Sistem Infomasi perpustakaan yang bisa mengubah waktu menjadi lebih efektif, untuk memperoses peminjaman dan pengembalian dengan otomatis dan menghasilkan informasi yang tentunya cepat dan tepat. Dalam pengembangan sistem Informasi yang akan dirancangkan pada MAN 10 Jakarta menggunakan metode waterfall, aplikasi ini menggunakan codeigniter dan phpmyadmin sebagai database dan Sublime text 3 untuk pembuatan aplikasi sistem informasi tersebut. Aplikasi atau sistem ini dapat mempermudah proses pencatatan dengan cara otomatisasi peminjaman dan pengembalian serta mempermudah proses pembuatan laporan bulanan dan lain-lain.
\end{abstract}

Kata Kunci - Codeigniter, Minat Belajar, Perpustakaan, PHP MySQL, Rapor Online, Sistem Informasi.

\section{PENDAHULUAN}

Perpustakaan merupakan sarana bagi siswa - siswi untuk dapat mencari ilmu, mencari beberapa referensi buku untuk dibaca maupun dipinjam. Pada setiap sekolah pasti terdapat perpustakaan untuk dimanfaatkan sebagai aktivitas instansi tersebut, dalam menjalankan kegiatan operasional diperlukan teknologi komputer, khususnya dalam pengolahan data ataupun penyajian informasi semuanya harus tersaji dengan tepat, cepat dan akurat serta berkualitas.

Demikian juga dengan Perpustakaan yang dimiliki oleh MAN 10 Jakarta yang memiliki perpustakaan sebagai pendukung sistem proses belajar. MAN 10 Jakarta adalah Perguruan atau Institusi Pendidkan yang bergerak di bidang pendidikan.

\footnotetext{
${ }^{1,2}$ Program Studi Sistem Informasi STMIK STMIK Antar Bangsa, Jl. HOS Cokroaminoto Kawasan Bisnis CBD Ciledug , Blok A5, No.29-36, Karang Tengah, Kota Tangerang; Telp. (021) 5098-6099; e-mail: elifitri774@gmail.com, april.firdha@gmail.com
}

Pemanfaatan teknologi informasi pada MAN 10 Jakarta masih menggunakan sistem yang belum terkomputerisasi. Untuk mendukung kegiatan operasional data-data yang dihasilkan kurang akurat karena masih terdapat data yang berulang, tidak tercatat, dan kurang teliti.

Berdasarkan latar belakang masalah, maka penulis membatasi ruang lingkup penelitian. Adapun batasan masalahnya hanya membahas yang berkaitan dengan pengolahan data anggota, data buku, data transaksi, dan data laporan. Tools yang digunakan untuk membangun sistem ini dengan menggunakan sublime text 3 serta menggunakan Codeigniter dengan database MySQL.

Permasalahan yang timbul dalam sistem peminjaman, pengembalian dan laporan buku pada perpustakaan MAN 10 Jakarta adalah masih menggunakan cara - cara manual, sehingga terjadi hambatan - hambatan dalam proses pelaksanaannya. Hambatan - hambatan tersebut antara lain:

Pencatatan yang dilakukan secara manual memakan waktu yang cukup lama. Sehingga dapat menyebabkan arsip - arsip hilang atau tercecer karena penyimpanan yang tidak baik. Apabila terjadi kesalahan pada pengisian data maka akan mengulang lagi dari awal untuk membetulkan kesalahan di karenakan proses yang masih manual.

Dalam penelitian mengenai perancangan sistem informasi perpustakaan SD Negeri Sukaharjo adalah tingkat sekolah dasar yang cukup besar, yang memiliki banyak koleksi buku. Kurangnya sistem informasi dan data pinjaman buku perpustakaan, membuat karyawan mengalami kesulitan dalam menjalankan administrasi perpustakaan. Dengan perkembangan teknologi saat ini pengolahan data perpustakaan yang saat ini berjalan di SDN Sukahrjo dianggap sudah tua. Dengan pengolahan data terkomputerisasi akan mempermudah pemantauan dan manajemen akan data buku diperpustakaan SDN Sukaharjo. [11].

Aplikasi sistem informasi perpustakaan akan dibuat sebagai otomasi perpustakaan yang bertujuan untuk memudahkan karyawan dalam pencarian data yang ada dan administrasi pinjaman buku dengan cepat, efektif dan efisien. Selain memberikan kemudahan pelayanan, sistem ini juga bertujuan untuk menghasilkan output dalam bentuk laporan yang akan digunakan sebagai acuan dalam akhir bulan. Dalam Penelitian ini membahas tentang Perancangan Sistem Informasi Berbasis Web untuk SMA Islam Sunan Gunung Jati pendataan yang dilakukan secara manual sehingga sering terjadi banyak kesalahan. Untuk itu perlu adanya sistem informasi perpustakaan berbasis web dimana manajemen data 
akan lebih tertata dan sesuai dengan keinginan pengguna. Metode penelitian yang digunakan adalah research and Development (R\&D) dengan pengembangan Extreme Programming. [12] Dalam penelitian tentang Sitem Informasi Perpustakaan Sekolah Berbasis Web, perubahan bentuk pengolahan data perpustakaan yang manual ke pengolahan data yang berbasis komputer menjadi solusi untuk mengatasi keterlambatan informasi dan kesulitan pengelolaan detail data koleksi buku-buku yang ada. Dengan perkembangan teknologi komunikasi data, sistem informasi perpustakaan sekolah dapat dibangun sebagai sistem informasi perpustakaan online (berbasis web). Tujuan dilakukannya penelitian ini adalah untuk menciptakan sebuah sistem informasi perpustakaan berbasis web yang dapat memberikan informasi perpustakaan yang cepat, tepat, dan akurat untuk anggota, petugas perpustakaan, dan pimpinan. Manfaat dari penelitian ini adalah diperolehnya kemudahan bagi anggota untuk mendapatkan buku-buku yang diperlukan, kemudahan untuk petugas perpustakaan mengolah data peminjaman, pengembalian, dan pemeliharaan koleksi buku sampai dihasilkannya informasi perpustakaan yang akan dipakai untuk pimpinan sebagai sumber pengambilan keputusan. Metode penelitian yang digunakan dalam penelitian ini adalah metode System Development Life Cycle (SDLC) dengan model Waterfall.

\section{TINJAUAN PUSTAKA}

\section{A. Pengertian Sistem Informasi}

Suatu sistem pada dasarnya adalah sekelompok unsur yang erat hubungannya satu dengan yang lain, yang berfungsi bersama-sama untuk mencapai tujuan tertentu. [1]

Sistem mengandung arti kumpulan-kumpulan dari komponen-komponen yang dimiliki unsur keterkaitan antara satu dengan yang lainnya. [2] Sistem adalah kumpulan elemen yang saling berhubungan dan saling berinteraksi satu sama lain untuk mencapai satu tujuan tertentu [3].

\section{B. Karakeristik Sistem}

Suatu sistem mempunyai beberapa karakteristik, yaitu komponen sistem, batasan sistem, lingkungan luar sistem, penghubung sistem, masukan sistem, keluaran sistem, pengolah sistem, dan sasaran sistem [4].

\section{Konsep Informasi}

Informasi adalah data yang telah diolah menjadi suatu bentuk yang penting bagi si penerima dan mempunyai nilai nyata atau yang dapat dirasakan dalam keputusan-keputusan yang sekarang atau keputusankeputusan yang akan datang [2]. Nilai dari informasi ditentukan dari 2 (dua) hal, yaitu manfaat dan biaya untuk mendapaatkannya. Suatu informasi dapat dikatakan bernilai apabila manfaat yangdiperoleh lebih berharga dibandingkan dengan biaya untuk mendapatkannya. [4]. Kualitas dari suatu informasi tergantung dari 3 (tiga) hal, yaitu informasi harus akurat (accurate), tepat waktu (timelines), dan relevan (relevance).
Fungsi utama informasi adalah untuk menambah pengetahuan atau mengurangi ketidak pastian pemakai informasi, karena informasi berguna memberikan gambaran tentang sesuatu permasalahan sehingga pengambil keputusan dapat menentukan keputusan lebih cepat, informasi juga memberikan standar, aturan maupun indikator bagi pengambil keputusan.

\section{Konsep Dasar Sistem Informasi}

Sistem informasi adalah suatu sistem didalam suatu organisasi yang mempertemukan kebutuhan pengolahan transaksi harian yang mendukung fungsi operasi organisasi yang bersifat manajerial dengan kegiatan strategi dari suatu organisasi untuk dapat menyediakan laporan-laporan yang diperlukan oleh pihak luar tertentu. [5]

Sistem informasi terdiri dari komponen yang disebutdengan istilah blok bangunan (building block), yang terdiri dari blok masukan, blok model, blok keluaran, blok teknologi, blok basis data, dan blok kendali. [7]

1. Blok masukan (input block)

Input mewakili data yang masuk ke dalam sistem informasi. Input disini termasuk metode-metode dan media yang digunakan untuk menangkap data yang akan dimasukkan, yang dapat berupa dokumen dasar. [5]

2. Blok model (model block)

Blok ini terdiri dari kombinasi prosedur, logika, dan model matematik yang akan memanipulasi data input dan data yang tersimpan di basis data dengan cara yang sudah tertentu untuk menghasilkan keluaran yang diinginkan. [8]

3. Blok keluaran (output block)

Produk dari sistem informasi adalah keluaran yang merupakan informasi yang berkualitas dan dokumentasi yang berguna untuk semua tingkatan manajemen serta semua pemakai sistem. [5]

4. Blok teknologi (technology block)

Teknologi digunakan untuk menerima input, menjalankan model, menyimpan dan mengakses data, menghasilkan dan mengirimkan keluaran dan membantu pengendalian sistem secara keseluruhan. Teknologi terdiri dari unsur utama: [6]

a) Teknisi (human ware atau brain ware)

b) Perangkat lunak (software)

c) Perangkat keras (hardware)

5. Blok basis data (database block)

Basis data (database) merupakan kumpulan data yang saling berhubungan satu dengan yang lainnya, tersimpan diperangkat keras komputer dan digunakan untuk memanipulasinya. [7]

6. Blok Kendali (control block)

Banyak faktor yang dapat merusak sistem informasi, misalnya bencana alam, api, temperature tinggi, air, debu, kecurangan-kecurangan, kejanggalan sistem itu sendiri, kesalahan-kesalahan, ketidak-efisienan, sabotase, dan lain sebagainya. Beberapa Pengendalian perlu dirancang dan diterapkan untuk meyakinkan bahwa hal-hal yang dapat merusak sistem dapat dicegah dan bila terlanjur terjadi kesalahan dapat langsung diatasi. [4] 


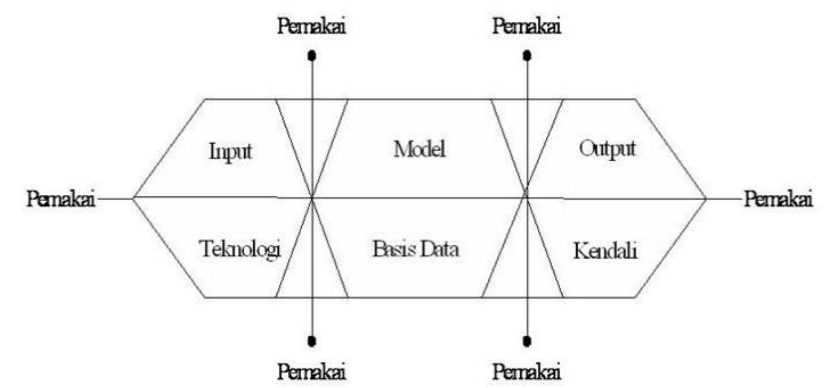

Sumber: [4]

Gbr 2 Blok sistem informasi yang berinteraksi

\section{E. Pengujian Kotak Hitam (Black-BoxTesting)}

Menguji perangkat lunak dari segi spesifkasi fungsional tanpa menguji desain dan kode program. Pengujian dimaksudkan untuk mengetahui apakah fungsi-fungsi, masukan, dan keluaran dari perangkat lunak sesuai dengan spesifikasi yang dibutuhkan [9]. Pengujian kotak hitam dilakukan dengan membuat kasus uji yang bersifat mencoba semua fungsi dengan memakai perangkat lunak apakah sesuai dengan spesifikasi yang dibutuhkan. Kasus uji yang dibuat untuk melakukan pengujian kotak hitam harus dibuat dengan kasus benar dan kasus salah, misalkan untuk kasus login maka kasus uji yang dibuat adalah [9]:

1) Jika user memasukkan nama pemakai (username) dan kata sandi (password) yang benar.

2) Jika user memasukkan nama pemakai (username) dan kata sandi (password) yang salah, misalnya nama pemakai benar dan kata sandi salah, atau sebaliknya, atau keduanya salah.

\section{F. Pengertian Perpustakaan}

Perpustakaan adalah mencakup suatu ruangan, bagian dari gedung, bangunan atau gedung tersendiri yang berisi bukubuku koleksi, yang diatur dan disusun demikian rupa, sehingga mudah untuk dicari dan dipergunakan apabila sewaktu-waktu diperlukan oleh pembaca. [4]

\section{G. Peralatan Pendukung (Tools System)}

1. Unified Modeling Language (UML)

Unified Modeling Language(UML) merupakan bahasa visual untuk pemodelan dan komunikasi mengenai sebuah sistem dengan menggunakan diagram dan teks-teks pendukung [9]. Berikut diagram dalam Unified Modeling Language(UML)

a. Use Case Diagram

Use case atau diagram use case merupakan pemodelan untuk melakukan (behavior) sistem informasi yang akan dibuat. Use case mendeskripsikan sebuah interaksi antara satu atau lebih aktor dengan sistem informasi yang akan dibuat. Secara kasar, use case digunakan untuk mengetahui fungsi apa saja yang ada dalam sebuah sistem informasi dan siapa saja yang berhak mengunakan fungsifungsi itu. Syarat penamaan pada use case adalah nama didefinisikan sesimpel mungkin dan dapat dipahami. Ada dua hal utama pada use case yaitu pendefinisian yang disebut aktor dan use case. Aktor merupakan orang, proses, sistem lain yang berinteraksi dengan sistem informasi yang akan dibuat diluar sistem informasi yang dibuat itu sendiri, jadi walaupun simbol dari aktor adalah ambar orang, tapi aktor belum tentu adalah orang. Use case merupakan fungsionalitas yang disediakan sistem sebagai unit-unit yang saling bertukar pesan antar unit atau aktor.

b. Activity Diagram

Activity Diagram dapat digunakan untuk menggambarkan bagaimana kegiatan dikoordinasikan untuk menyediakan layanan pada berbagai tingkat abstraksi. Karena activity diagram mendukung dan mendorong perilaku paralel. Activity diagram juga dapat menggambarkan tautan ke suatu objek dengan memberi label aktivitas dengan nama objek atau dengan menggunakan "swimlame", yang memungkinkan diagram aktivitas disusun berdasarkan tanggung jawab [10].

c. Class Diagram

Diagram Kelas atau class diagram menggambarkan struktur sistem dari segi pendefinisien kelas-kelas yang akan dibuat untuk membangun sistem kelas memiliki apa yang disebut atribut dan metode dan operasi.

1) Atribut merupakan variable-variabel yang dimiliki oleh suatu kelas.

2) Operasi atau metode adalah fungsi-fungsi yang dimiliki oleh suatu kelas.

Diagram kelas dibuat agar pembuat program atau programmer membuat kelas-kelas sesuai rancangan didalam diagram kelas agar antara dokumentasi perancangan dan perangkat lunak sinkron. Banyak berbagai kasus, perancangan kelas yang dibuat tidak sesuai dengan kelas-kelas yang dibuat pada perangkat lunak, sehingga tidaklah ada gunanya lagi sebuah perancangan karena karena apa yang dirancang dan hasil jadinya tidak sesuai.

d. Component Diagram

Diagram Komponen atau Component diagram dibuat untuk menunjukkan organisasi dan ketergantungan diantara kumpulan komponen dalam sebuah sistem. Diagram komponen fokus pada komponen sistem yang dibutuhkan dan ada di dalam sistem. Diagram komponen juga dapat digunakan untuk memodelkan hal-hal berikut:

1) Source code program perangkat lunak

2) Komponen executable yang di lepas ke user

3) Basis data secara fisik

4) Sistem yang harus beradaptasi dengan sistem lain

5) Framework sistem, framework pada perangkat lunak merupakan kerangka kerja yang dibuat untuk memudahkan pengembangan dan pemeliharaan aplikasi, contohnya seperti Struts dari Apache yang menggunakan prinsip desain Model-View-Controler (MVC) di mana source code program dikelompokkan berdasarkan fungsinya. Dimana controller berisi source code yang menangani request dan validasi, model berisi source code yang menangani manipulasi data dani 0 , dan view berisi source code yang menagani tampilan. 
e. Deployment Diagram

Deployment diagram menunjukkan konfigurasi komponen dalam proses eksekusi aplikasi. Diagram deployment juga diguanakan untuk memodelkan hal-hal berikut:

1) Sistem tambahan (embedded system) yang menggambarkan rancangan device, node dan hardware.

2) Sistem client/server

f. Sequence Diagram

Diagram sekuen menggambarkan kelakuan objek pada use case dengan mendeskripsikan waktu hidup objek dan message yang dikirimkan dan diterima antar objek. Oleh karena itu untuk menggambar diagram sekuen maka harus diketahui objek-objek yang terlibat dalam sebuah use case beserta metode-metode yang dimiliki kelas yang di instansiasi menjadi objek itu. Membuat diagram sekuen juga dibutuhkan untuk melihat skenario yang ada pada use case. Banyaknya diagram sekuen yang harus digambar adalah minimal sebanyak pendefenisian use case yang memiliki proses sendiri atau yang penting semua use case yang telah didefenisikan interaksi jalannya pesan sudah dicakup pada diagram sekuen sehingga semakin banyak use case yang didefenisikan maka diagram sekuen yang akan dibuat juga semakin banyak.

\section{METODE PENELITIAN}

Berikut ini penulis menguraikan metode penelitian agar dapat melengkapi tugas akhir ini yaitu :

A. Teknik Pengumpulan Data

1. Observasi

Observasi dilakukan langsung ke perpustakaan MAN 10 Jakarta. Observasi dilakukan untuk mengetahui bagaimana jalannya sirkulasi peminjaman buku di perpustakaan dan mengetahui masalah-masalah pada sistem perpustakaan yang berjalan secara manual.

2. Wawancara

Dalam wawancara dapat diperoleh hasil bahwa masalah yang terjadi pada sistem perpustakaan MAN 10 Jakarta terdapat pada sirkulasi peminjaman buku, pengembalian buku,dan laporan setiap bulannya.

3. Studi Pustaka

Penelitian ini dilakukan dengan mempelajari buku-buku, penulisan ilmiah maupun catatan perkuliahan sebagai bahanreferensi yang berkaitan dengan masalah yang dibahas.

\section{B. Model Pengembangan Sistem}

Metode pengembangan sistem yang digunakan dalam penulisan skripsi ini adalah dengan menggunakan model pengembangan secara waterfall. Dalam metode waterfall terdiri dari beberapa tahapan, yaitu :

1) Analisa Kebutuhan Sistem

2) Desain

3) Code Generation

4) Testing

5) Support

\section{PEMBAHASAN DAN HASIL}

Sistem informasi Perpustakaan berbasis web merupakan sebuah sistem informasi yang berfungsi untuk mengelola informasi yang diperlukan di perpustakaan seperti bahan pustaka berupa data anggota, data buku, data proses transaksi, data denda, data petugas serta proses pembuatan laporan. Berikut ini spesifikasi kebutuhan (system requitmen) dari sistem perpustakaan:

Halaman Admin:

A.1.Admin dapat melihat home

A.2.Admin dapat melihat tentang

A.3 Admin dapat melihat list buku

A.4.Admin dapat melihat info peminjaman

A.5.Admin dapat melakukan login

A.6.Admin dapat melihat dashboard setelah login

A.7.Admin dapat mengelola data master anggota setelah login

A.8.Admin dapat mengelola data master buku setelah login

A.9.Admin dapat mengelola data transaksi setelah login

A.10.Admin dapat mengelola data denda setelah login

A.11.Admin dapat mengelola data petugas setelah login

A.12. Admin dapat melakukan logout

Halaman Petugas:

B.1.Petugas dapat melihat home

B.2.Petugas dapat melihat tentang

B.3.Petugas dapat melihat list buku

B.4.Petugas dapat melihat info peminjaman

B.5.Petugas dapat melakukan login

B.6.Petugas dapat melihat dashboard setelah login

B.7.Petugas dapat mengelola data master anggota setelahlogin

B.8.Petugas dapat mengelola data master buku setelah login

B.9.Petugas dapat mengelola data transaksi setelah login

B.10.Petugas dapat mengelola data denda setelah login

B.11.Petugas dapat melakukan logout

Halaman Anggota :

C.1.Anggota dapat melihat home

C.2.Anggota dapat melihat list buku

C.3.Anggota dapat melihat tentang sekolah

C.4 Anggota dapat melihat info peminjaman

1. Use Case Diagram Halaman Anggota

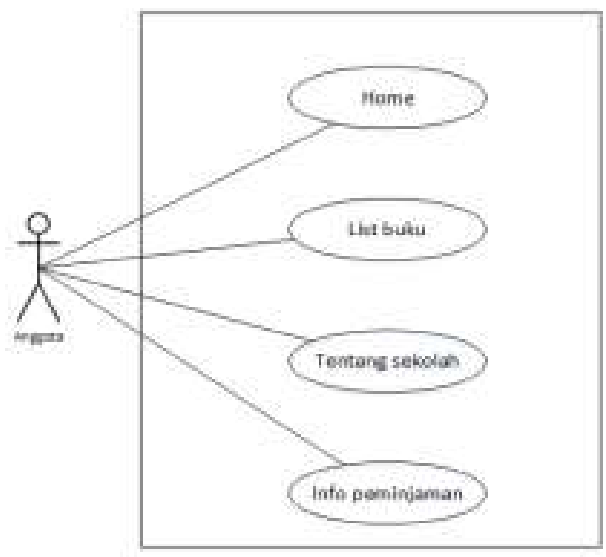

Gbr 3 Use Case Diagram Halaman Anggota 
2. Use Case Halaman Admin

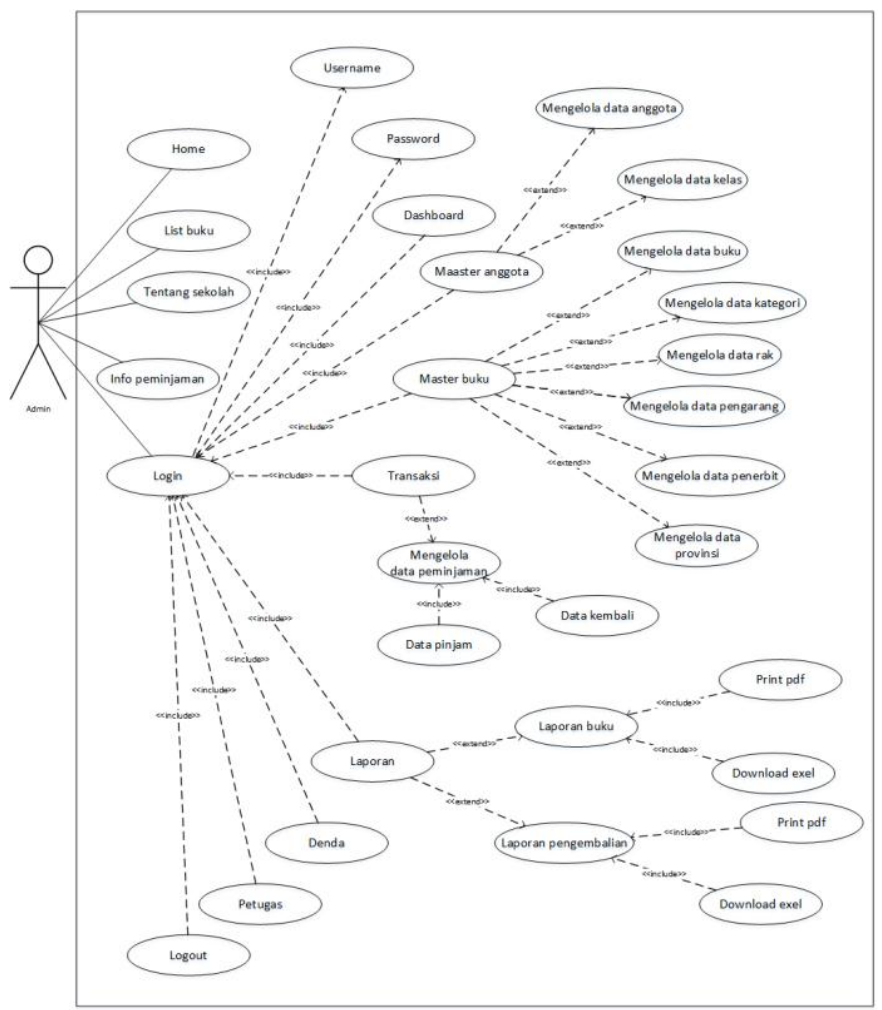

Gbr 4 Use Case Diagram Admin

3. Use Case Diagram Halaman Petugas

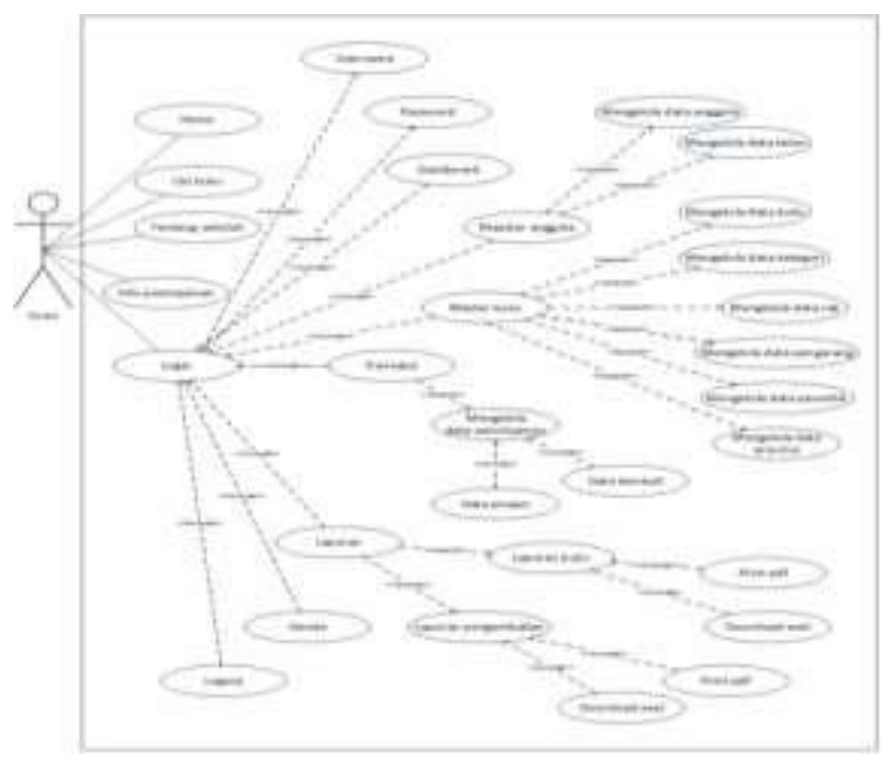

Gbr 5 Use Case Diagram Petugas
4. Activity Diagram Login

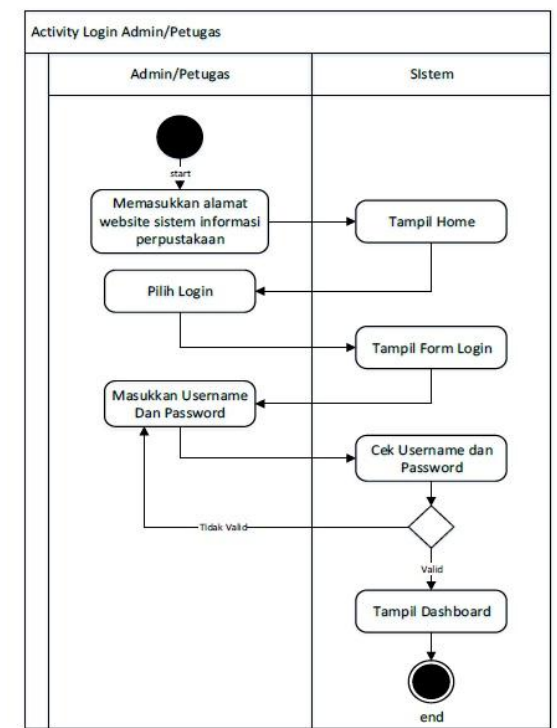

Gbr 7 Activity Diagram Login Admin dan petugas

5. Activity Diagram Data Buku

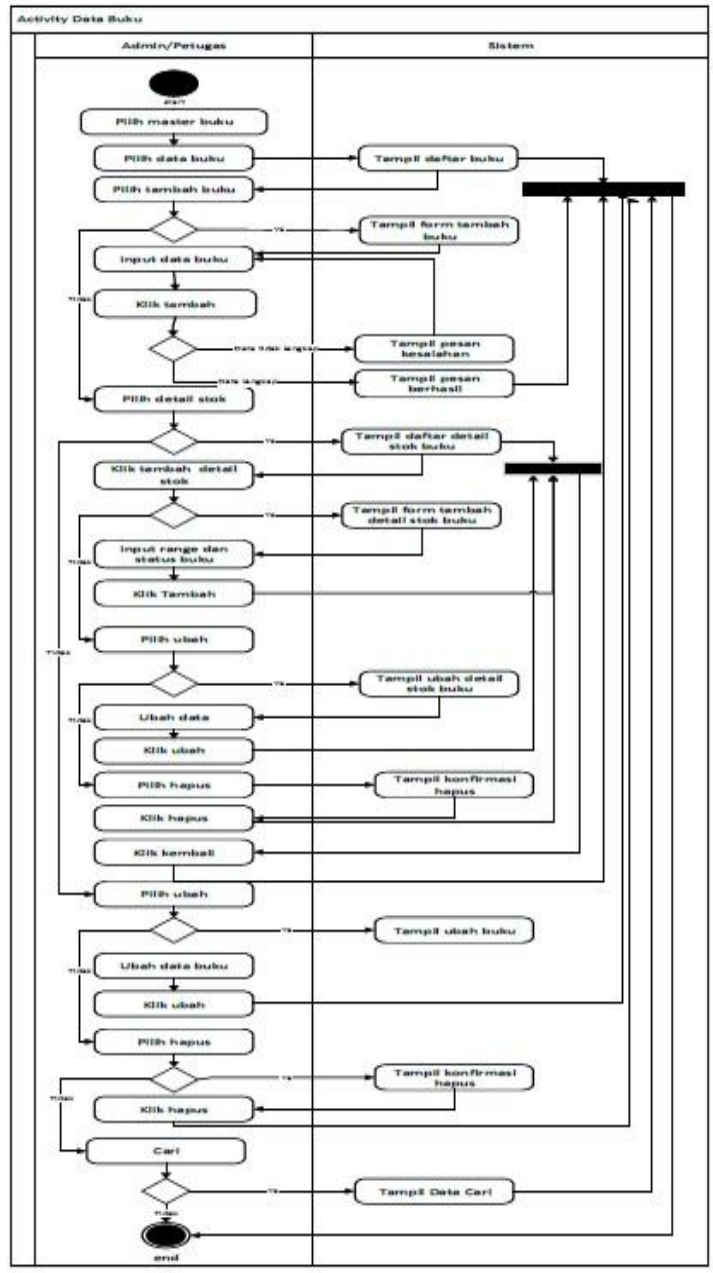

Gbr 8 Activity Diagram Data Buku 
6. Activity Diagram Data Peminjaman

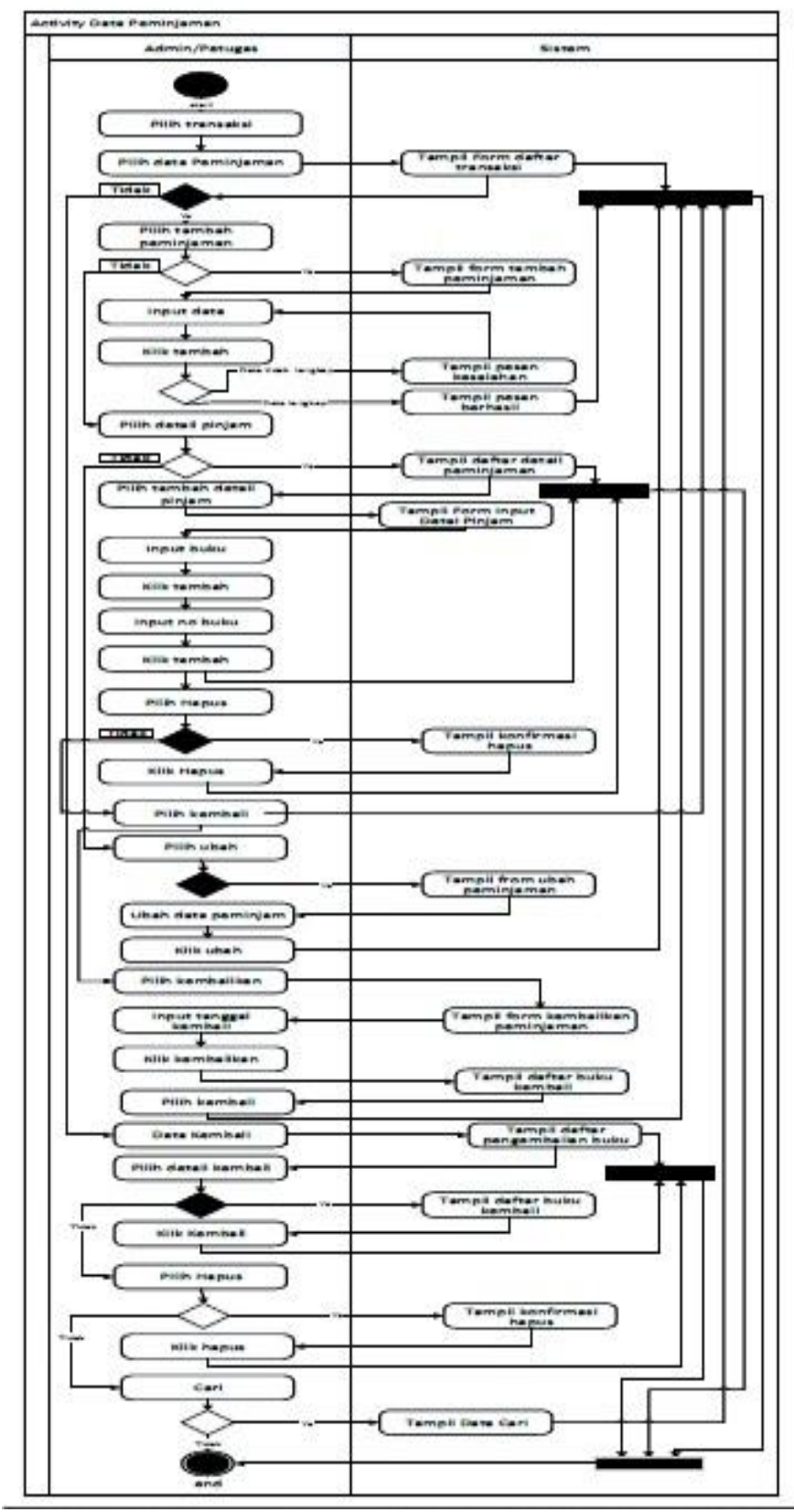

Gbr 9 Activity Diagram Data Peminjaman
7. Class Diagram

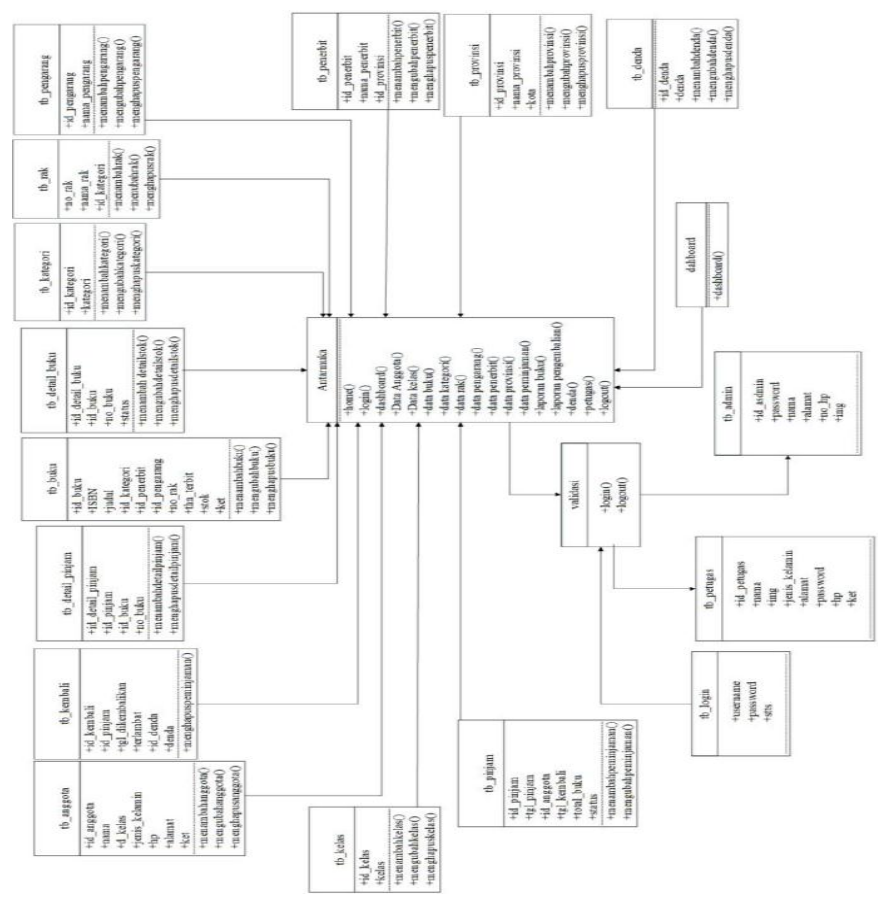

Gbr 10 Class diagram sistem informasi perpustakaan

8. Sequence diagram Data Buku

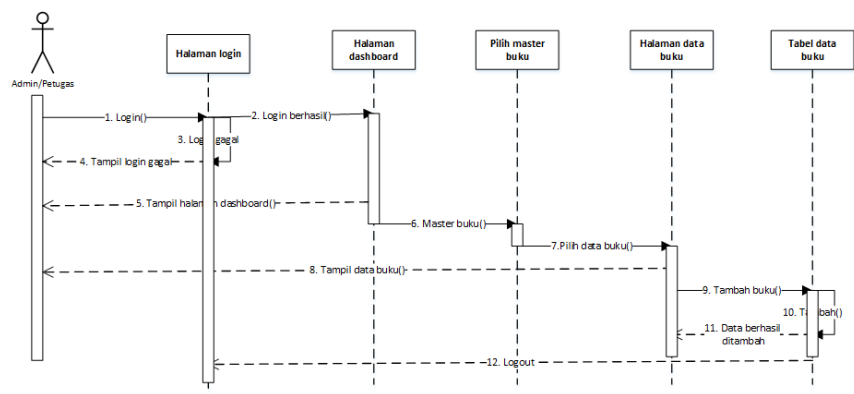

Gbr 11. Sequence Diagram Data Buku

9. Sequence diagram Transaksi



Gbr 12 Sequence Diagram Transaksi 


\section{Deployment Diagram}

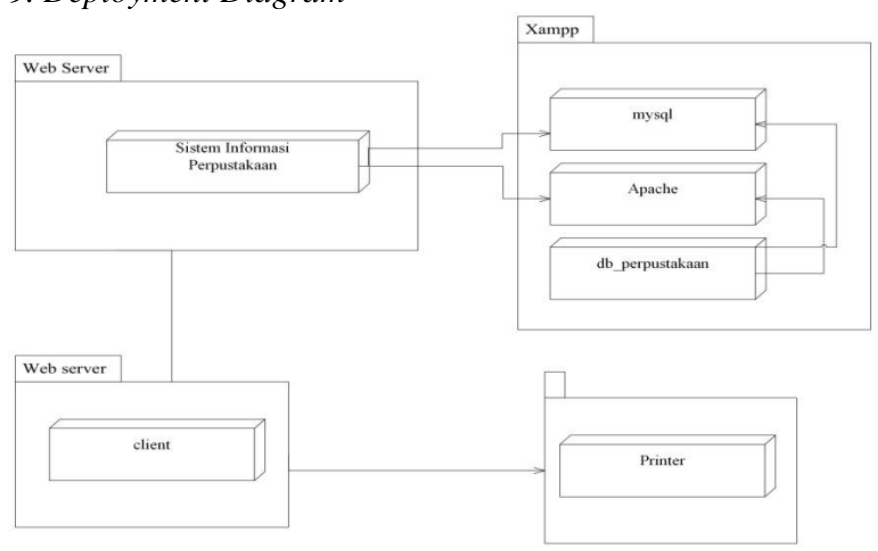

Gbr 13 Deployment Diagram Sistem Informasi Perpustakaan

\section{Component Diagram}

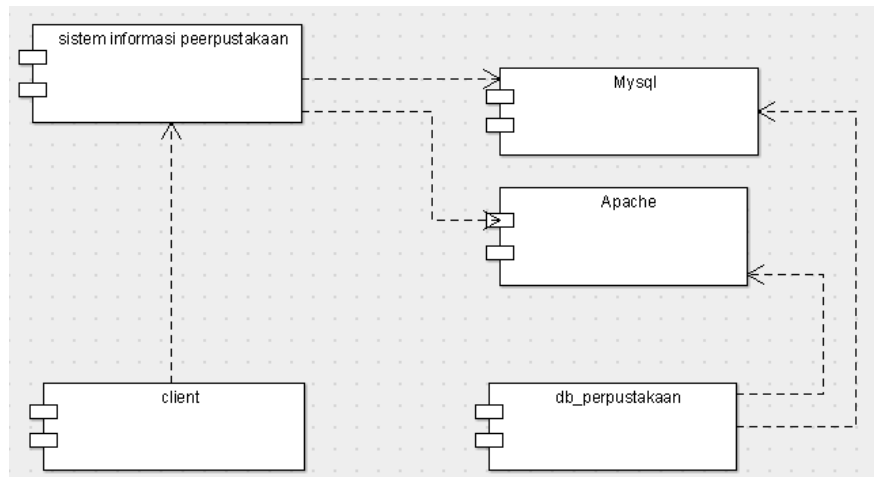

Gbr 14 Component Diagram Sistem Informasi Perpustakaan

Dalam sistem usulan, penulis juga menjelaskan rancangan sistem yang dibuat. Rancangan tersebut berupa tampilan tampilan interface yang sudah siap diuse dan diaplikasikan.Berikut adalah tampilan aplikasinya :

1. Tampilan Halaman Home

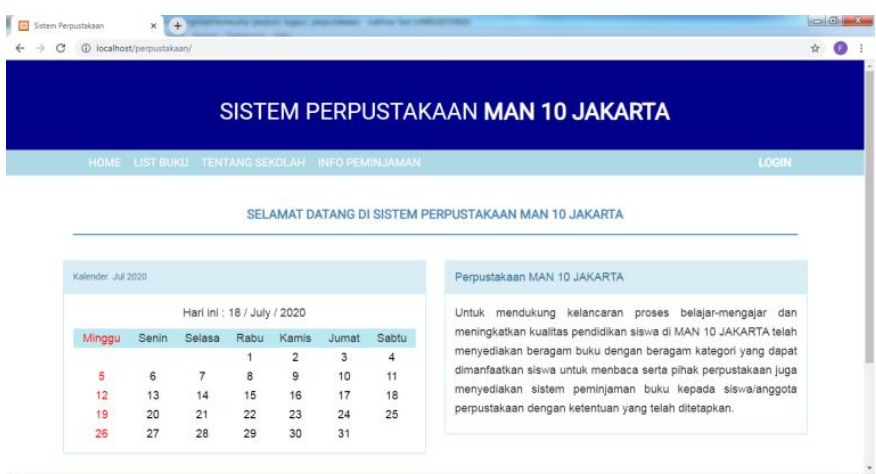

Gbr 15 Tampilan Home Admin/Petugas/Anggota
2. Tampilan Halaman Login

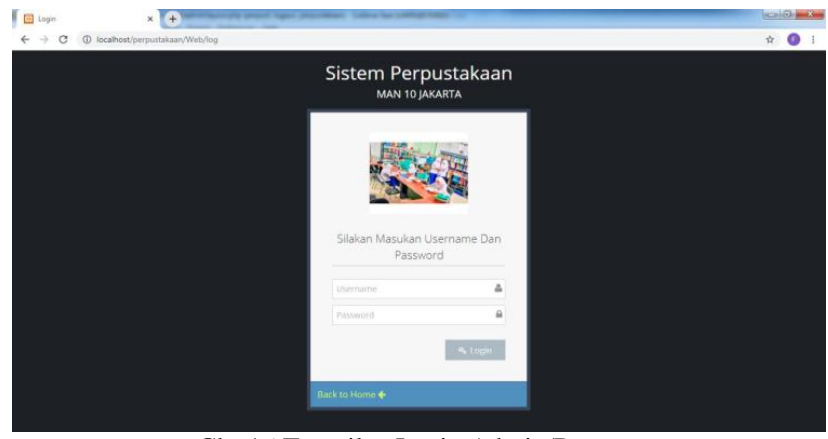

Gbr 16 Tampilan Login Admin/Petugas

3. Halaman Data Anggota

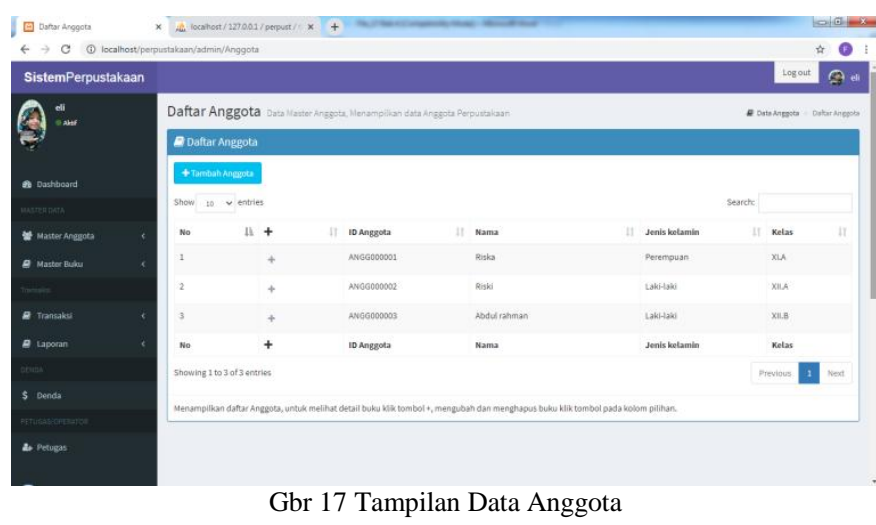

4. Halaman Data Buku

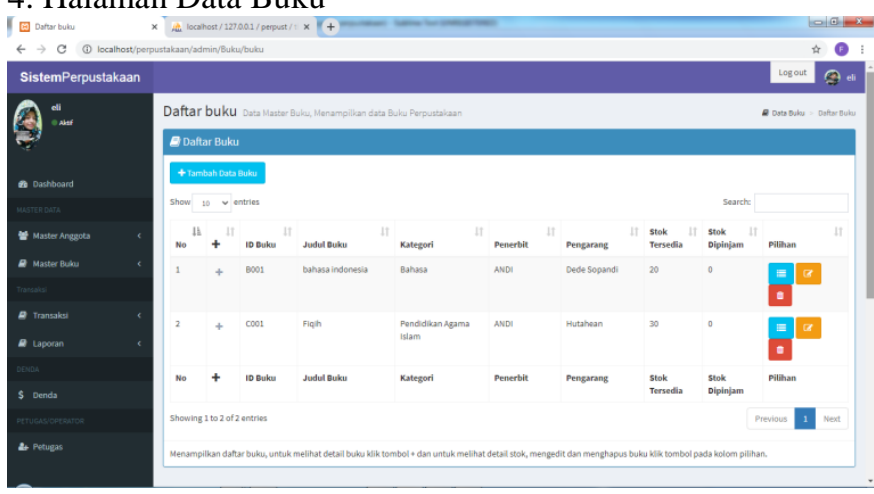

Gbr 18 Tampilan Data Buku

5. Halaman Data Pinjam Buku

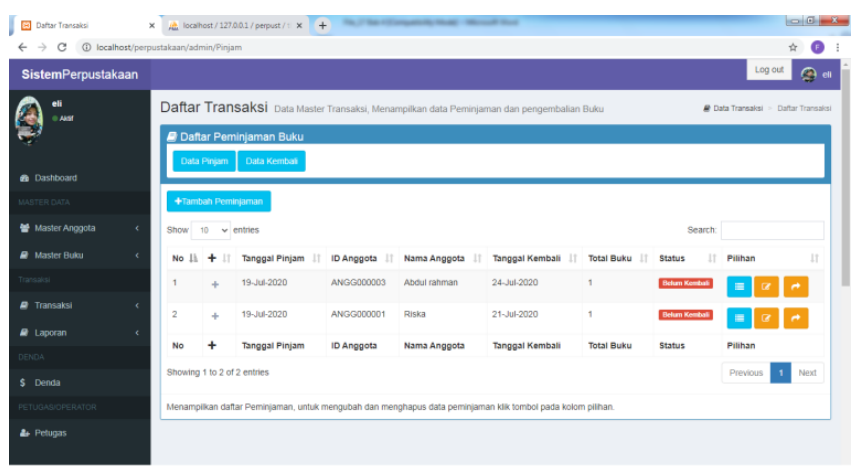

Gbr 19 Tampilan Data Pinjam Buku 


\section{JURNAL SISTEM INFORMASI STMIK ANTAR BANGSA \\ [VOL.X NO.1 - FEBRUARI 2021]}

\section{Halaman Form Kembali Buku}

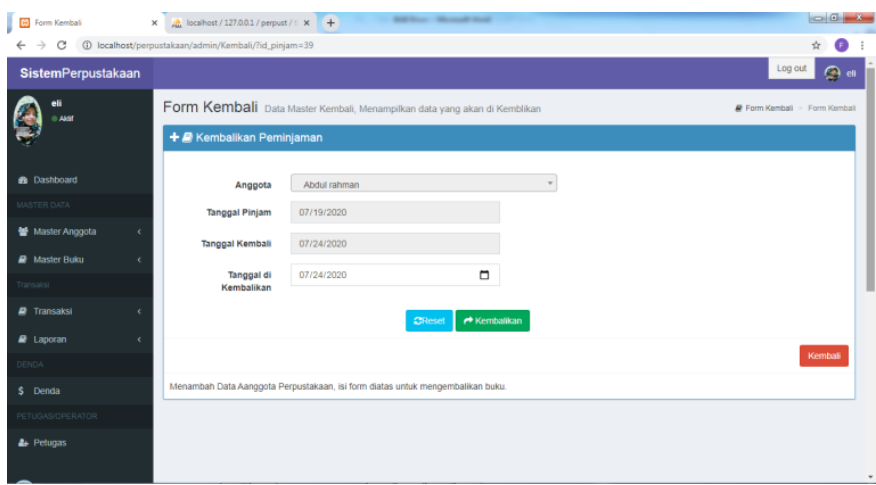

Gbr 20 Tampilan Form Kembali Peminjaman Buku

\section{Halaman Detail Kembali Buku}

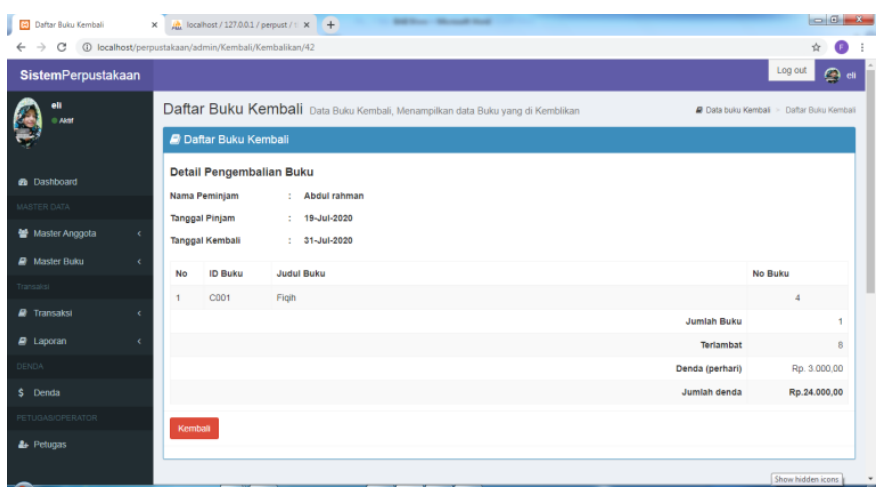

Gbr 21 Tampilan Data Detail Kembali Buku

8. Halaman Daftar Laporan Buku

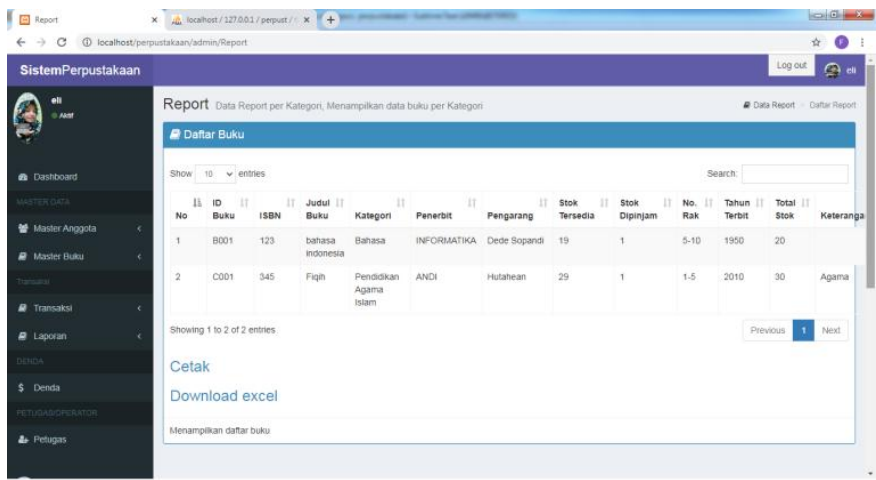

Gbr 22 Tampilan Daftar Laporan Buku

Dalam penelitian ini penulis melakukan pengujian sengan menggunakan Blackbox testing
1. Form Data Anggota

TABEL I

BLACK BOX TESTING FORM DATA ANGGOTA

\begin{tabular}{clllll}
\hline No & $\begin{array}{c}\text { Skenario } \\
\text { Pengujian }\end{array}$ & $\begin{array}{c}\text { Test } \\
\text { Case }\end{array}$ & $\begin{array}{c}\text { Hasil yang } \\
\text { diharap } \\
\text { kan }\end{array}$ & $\begin{array}{c}\text { Hasil } \\
\text { Pengu } \\
\text { jian }\end{array}$ & $\begin{array}{c}\text { Kesim } \\
\text { pulan }\end{array}$ \\
\hline 1. & $\begin{array}{l}\text { Mengosong } \\
\text { kan semua }\end{array}$ & $\begin{array}{l}\text { Semua } \\
\text { Data }\end{array}$ & $\begin{array}{l}\text { Sistem } \\
\text { akan }\end{array}$ & $\begin{array}{l}\text { Sesuai } \\
\text { harapan }\end{array}$ & Valid \\
& isian form & Kosong & menolak & & \\
& input, lalu klik & & dan & & \\
& tambah & & menampil & & \\
& & & kan pesan & & \\
& & & "Please & \\
& & & fill out & \\
& & & & \\
& & & this fild." & \\
\hline
\end{tabular}

\begin{tabular}{|c|c|c|c|c|c|}
\hline 2. & $\begin{array}{l}\text { Hanya } \\
\text { mengisi salah } \\
\text { satu form } \\
\text { inputan, dan } \\
\text { yang lain } \\
\text { dikosongkan, } \\
\text { lalu klik } \\
\text { tambah }\end{array}$ & $\begin{array}{l}\text { Nama: } \\
\text { eli } \\
\text { dan data } \\
\text { yang } \\
\text { lain } \\
\text { kosong }\end{array}$ & $\begin{array}{l}\text { Sistem } \\
\text { akan } \\
\text { menolak } \\
\text { dan } \\
\text { menampil } \\
\text { kan pesan } \\
\text { "please } \\
\text { select one } \\
\text { of these } \\
\text { option" }\end{array}$ & $\begin{array}{l}\text { Sesuai } \\
\text { harapan }\end{array}$ & Valid \\
\hline 3. & $\begin{array}{l}\text { Mengisi } \\
\text { semua form } \\
\text { inputan, lalu } \\
\text { klik tambah }\end{array}$ & 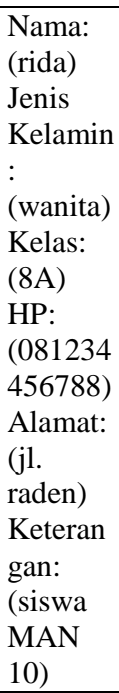 & $\begin{array}{l}\text { Sistem } \\
\text { akan } \\
\text { menerima } \\
\text { dan } \\
\text { menampil } \\
\text { kan pesan } \\
\text { "Data } \\
\text { Berhasil } \\
\text { disimpan! } \\
\text { " }\end{array}$ & $\begin{array}{l}\text { Sesuai } \\
\text { harapan }\end{array}$ & Valid \\
\hline
\end{tabular}

TABEL II

BLACK BOX TESTING FORM DATA PEMINJAMAN

\begin{tabular}{|c|c|c|c|c|c|}
\hline No & $\begin{array}{l}\text { Skenario } \\
\text { Pengujian }\end{array}$ & $\begin{array}{l}\text { Test } \\
\text { Case }\end{array}$ & $\begin{array}{l}\text { Hasil yang } \\
\text { diharapkan }\end{array}$ & $\begin{array}{l}\text { Hasil } \\
\text { Pengu } \\
\text { jian }\end{array}$ & $\begin{array}{l}\text { Kesim } \\
\text { pulan }\end{array}$ \\
\hline 1. & $\begin{array}{l}\text { Mengoson } \\
\text { gkan } \\
\text { semua } \\
\text { isian form } \\
\text { input, lalu } \\
\text { klik } \\
\text { tambah }\end{array}$ & $\begin{array}{l}\text { Semua } \\
\text { Data } \\
\text { Kosong }\end{array}$ & $\begin{array}{l}\text { Sistem akan } \\
\text { menolak dan } \\
\text { menampil kan } \\
\text { pesan"inputan } \\
\text { tidak terisi } \\
\text { dengan benar. } \\
\text { Cek kembali! }\end{array}$ & $\begin{array}{l}\text { Sesuai } \\
\text { harapan }\end{array}$ & Valid \\
\hline
\end{tabular}




\begin{tabular}{|c|c|c|c|c|c|}
\hline 2. & $\begin{array}{l}\text { Hanya } \\
\text { mengisi } \\
\text { salah satu } \\
\text { form } \\
\text { inputan, } \\
\text { dan yang } \\
\text { lain } \\
\text { dikosongk } \\
\text { an, lalu } \\
\text { klik } \\
\text { tambah } \\
\end{array}$ & $\begin{array}{l}\text { Anggota } \\
\text { : (Rida) } \\
\text { Tanggal } \\
\text { kembali: } \\
\text { (kosong } \\
\text { ) }\end{array}$ & $\begin{array}{l}\text { Sistem akan } \\
\text { menolak dan } \\
\text { menampilkan } \\
\text { pesan"inputan } \\
\text { tidak terisi } \\
\text { dengan benar. } \\
\text { Cek kembali! }\end{array}$ & $\begin{array}{l}\text { Sesuai } \\
\text { harapan }\end{array}$ & Valid \\
\hline 3. & $\begin{array}{l}\text { Mengisi } \\
\text { semua } \\
\text { form } \\
\text { inputan, } \\
\text { lalu klik } \\
\text { tambah }\end{array}$ & $\begin{array}{l}\text { Anggota } \\
\text { : (Rida) } \\
\text { Tanggal } \\
\text { kembali: } \\
\text { (kosong } \\
\text { ) }\end{array}$ & $\begin{array}{l}\text { Sistem akan } \\
\text { menerima dan } \\
\text { menampilkan } \\
\text { pesan "Data } \\
\text { Berhasil } \\
\text { disimpan!" }\end{array}$ & $\begin{array}{l}\text { Sesuai } \\
\text { harapan }\end{array}$ & Valid \\
\hline 4. & $\begin{array}{l}\text { Mengoson } \\
\text { gkan } \\
\text { inputan } \\
\text { buku detail } \\
\text { pinjam, } \\
\text { lalu klik } \\
\text { tambah }\end{array}$ & $\begin{array}{l}\text { Anggota } \\
\text { : (terisi) } \\
\text { Tanggal } \\
\text { kembali: } \\
\text { (terisi) } \\
\text { Buku: } \\
\text { (kosong } \\
\text { ) }\end{array}$ & $\begin{array}{l}\text { Sistem akan } \\
\text { menolak dan } \\
\text { menampilkan } \\
\text { pesan"inputan } \\
\text { tidak terisi } \\
\text { dengan benar. } \\
\text { Cek kembali! }\end{array}$ & $\begin{array}{l}\text { Sesuai } \\
\text { harapan }\end{array}$ & Valid \\
\hline 5. & $\begin{array}{l}\text { Mengisi } \\
\text { semua } \\
\text { form } \\
\text { inputan, } \\
\text { lalu klik } \\
\text { tambah }\end{array}$ & $\begin{array}{l}\text { Anggota } \\
\text { : (terisi) } \\
\text { Tanggal } \\
\text { kembali: } \\
\text { (terisi) } \\
\text { Buku: } \\
\text { (terisi) } \\
\text { No } \\
\text { buku: } \\
\text { (terisi) }\end{array}$ & $\begin{array}{l}\text { Sistem akan } \\
\text { menerima dan } \\
\text { menampilkan } \\
\text { pesan "Data } \\
\text { Berhasil } \\
\text { disimpan!" }\end{array}$ & $\begin{array}{l}\text { Sesuai } \\
\text { harapan }\end{array}$ & Valid \\
\hline
\end{tabular}

\section{KESIMPULAN}

Dari hasil pengamatan dan analisa yang telah dilakukan pada perpustakaan Man 10 Jakarta, pembuatan sistem informasi ini dapat menghasilkan :

1. Sistem informasi perpustakaan berbasis web sebagai media pencatatan data pengolahan perpustakaan MAN 10 Jakarta dengan memberikan informasi yang dibutuhkan secara cepat dan tepat.

2. Sistem informasi perpustakaan berbasis web ini dapat membantu pengolahan data anggota, data buku, data transaksi, dan data laporan.

3. Sistem informasi pada sistem informasi perpustakaan dapat menyajikan laporan - laporan data seperti yang tercantum pada point no. 2 .

\section{REFERENSI}

[1] G. W. Sasmito, "Penerapan Metode Waterfall Pada Desain Sistem Informasi Geografi Industri Kabupaten Tegal," Jurnal pengembangan IT, vol. 2, no. 1, p. 8, 2017.
2] T. Sutabri, Analisa Sistem Informasi, Yogyakarta: Andi Offset, 2012.

[3] J. Hutahean, Konsep Sistem Informasi, Yogyakarta: deepublish, 2016.

[4] K. Yuliana, "Analisa Sistem Informasi Dan Pengembalian Buku Perpustakaan Pada SMA Nusantara," STMIK Raharja Jurusan Sistem Informasi, p. 48, 2018.

[5] R. A. S and M, Shalahuddin, Rekayasa Perangkat Lunak Terstruktur dan Berorientasi Objek, Bandung: Informatika Bandung, 2016.

[6] Atom, "Avtivity Diagram," Studi Pustaka, 12102019. [Online]. Available: webstudi.site/2019/11/ActivityDiagram.html. [Accessed 1210 2019].

[7] Fajar Hariadi and Sukadi, "Perancangan Sistem Informasi Perpustakaan Pada Sekolah Dasar Negeri Sukaharjo Pacitan," Indonesian Journal on Networking and Security, p. 1, 2013.

[8] N. Fatimah and Yandria Elmasari, "Perancangan Sistem Informasi Perpustakaan Berbasis Web Untuk Sunan," JIP(Jurnal Ilmiah dan Penelitian Informasi, vol. 03, no. 02, p. 130, 2018.

[9] D. PuspitaSARI, "Sistem Informasi Perpustakaan Sekolah Berbasis Web," Jurnal Pilar Nusa Mandiri, vol. XII, no. No.1, p. 228, 2016.

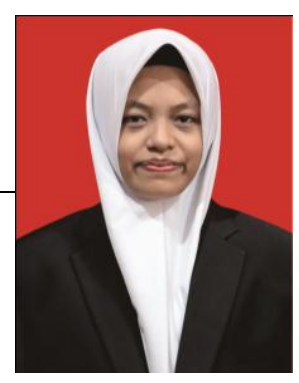

Eli Fitriatun. Lahir di Lombok pada Tanggal 01 Oktober 1998. Tahun 2020 lulus dari Program Strata Satu (S1) Jurusan Sistem Informasi di STMIK Antar Bangsa. Saat ini melakukan pengabdian di LAZ YMMPI.

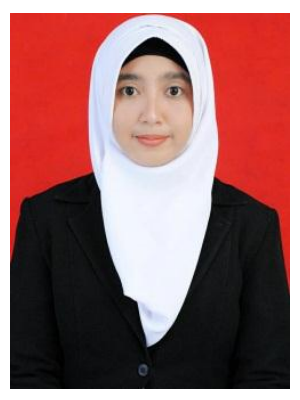

Firdha Aprilyani. Lahir di Tangerang pada Tanggal 20 April 1993. Lulus dari Program Strata Satu (S1) Jurusan Sistem Informasi di STMIK Antar Bangsa pada Tahun 2015. Lulus dari Program Pasca Sarjana (S2) Teknologi Sistem Informasi, Universitas Budi Luhur Konsentrasi Teknologi Sistem Informasi pada tahun 2018. Saat ini aktif sebagai Dosen Tetap di STMIK Antar Bangsa, aktif sebagai peneliti dan penulis jurnal ilmiah, serta aktif sebagai anggota Asosiasi Perguruan Tinggi Ilmu Komputer (APTIKOM) dan Asosiasi Dosen Indonesia (ADI). 